\title{
Protein, Organized by Structure
}

National Cancer Institute

\section{Source}

National Cancer Institute. Protein, Organized by Structure. NCI Thesaurus. Code C20028.

Organizing term for the Proteins tree 